\title{
THE EFFECT OF THEOPHYLLINE ETHYLENE DIAMINE ON RENAL FUNC- TION IN CONTROL SUBJECTS AND IN PATIENTS WITH CONGESTIVE HEART FAILURE ${ }^{1}$
}

\author{
By JAMES O. DAVIS ${ }^{2}$ AND NATHAN W. SHOCK \\ (From the Section on Cardiovascular Diseases and Gerontology, National Heart Institute, \\ National Institutes of Health, Bethesda, Maryland, and the Baltimore \\ City Hospitals, Baltimore)
}

(Received for publication February 26, 1949)

The importance of a renal factor in the pathogenesis of peripheral cardiac edema has been emphasized in recent publications (1-11). The work of Futcher and Schroeder (1) indicated that the renal excretion of salt and water was impaired during cardiac decompensation. Numerous other workers $(4-6,10,11)$ reported a reduction in renal blood flow, glomerular filtration rate, and sodium excretion in cases of cardiac failure. These studies resulted in the formulation of two principal hypotheses to explain the retention of sodium and water; namely, (1) low glomerular filtration rate, and (2) more complete reabsorption of sodium and water. More recently, Wesson, Anslow, and Smith (12) have suggested that the low filtration rate delivers a sodium load to the distal tubule which is less than the $T_{m}$ for sodium and leads to more complete distal tubular reabsorption of sodium.

The purpose of this investigation was to study the renal mechanism of sodium and water excretion in cardiac failure by observing the effect of theophylline ethylene diamine (T.E.D.) on filtration rate, effective renal plasma flow, and sodium clearance. Since the results of preliminary experiments suggested that T.E.D. not only increased the tubular load of sodium but also decreased sodium reabsorption, the relationship between tubular load and excretion of sodium could not be determined. However, the simultaneous measurement of filtration rate and sodium clearance during the control periods in patients with

1 We are indebted to Clifford Grant, Jr., Carol Fisher, Margaret McCollom, Elsie Beard, Patricia Nichols, Georgia Proferes, Patricia Skinner, Janis Parsons and Jesse Yaffa for technical assistance. Dr. James Birren offered suggestions concerning the statistical treatment of the data. Dr. H. E. Harrison offered many helpful criticisms.

2 Present address : Cardiovascular Clinic, U. S. Marine Hospital, Baltimore, Maryland. cardiac failure afforded an opportunity to study the degree of correlation of these functions under resting conditions. Since the evidence for the mechanism of xanthine diuresis in man is conflicting $(4,11)$, an extensive study of control subjects was made.

\section{MATERIALS AND METHODS}

\section{Subjects}

Male subjects were selected from the wards of the the Baltimore City Hospitals and Infirmary (Home for the Aged).

Control subjects were chosen on the basis of a history, physical examination, chest roentgenogram, and urinalysis; cases with hypertension, cardiac and renal diseases were excluded. Although they were selected irrespective of age, most of them were over 50 (range $=36-$ 78 , mean $=60$ ). All subjects were on a regular diet without salt restriction.

The patients in congestive heart failure were selected on the basis of clinical findings characteristic of cardiac decompensation. The majority had experienced repeated episodes of cardiac failure. Individual protocols are as follows :

Case 1, C. $M$. A 63-year-old colored male was readmitted with congestive heart failure for the third time on $10 / 30 / 47$. When renal function was studied on $2 / 26 / 48$, physical examination revealed a pulse of 88 , a blood pressure of $132 / 84$, and a respiratory rate of 30 . He was dyspneic, orthopneic, and edematous. Moist râles were present at both lung bases. A harsh systolic murmur was audible at the apex. An X-ray of the chest revealed generalized cardiac enlargement and pulmonary congestion. An electrocardiogram showed myocardial disease and a tendency toward right axis deviation. The diet was regular. Treatment consisted of digitalis and mercupurin; the last injection of mercupurin was nine days prior to the experiment.

Case 2, J. $P$. A 43-year-old white male entered the hospital with cardiac decompensation for the third time on $3 / 5 / 48$. Five weeks prior to the present admission he discontinued digitalis; signs of left and right heart failure ensued. On the day of the renal function studies, $3 / 8 / 48$, physical examination revealed a pulse of 80 , a blood pressure of 120/88, and a respiratory rate of 22 . 
He was dyspneic and orthopneic, and râles were present at both lung bases. A harsh, apical, systolic murmur and a localized, apical, mid-diastolic murmur were present. An X-ray of the chest revealed cardiac enlargement with a typical mitral configuration and pulmonary congestion. An electrocardiogram showed auricular fibrillation, myocardial disease, and right axis deviation. He received a Karrell diet, and 2 cc. of mercupurin were given two days before the experiment.

Case 3, A. W. A 39-year-old colored male entered the hospital with cardiac failure for the seventh time on $3 / 17 / 48$. Physical examination on the day of the experiment $3 / 22 / 48$ revealed a pulse of 100 , a blood pressure of $120 / 80$, and a respiratory rate of $32 .^{\circ} \mathrm{He}$ was dyspneic and orthopneic. Moist râles were present throughout the lower portion of both lungs. A loud, harsh, moderately high-pitched, systolic murmur and a short, low-pitched, pre-systolic murmur were audible at the apex. An X-ray of the chest revealed cardiomegaly with a mitral configuration and pulmonary congestion. An electrocardiogram showed left bundle branch block, myocardial disease, and ventricular premature contractions. The liver was enlarged; ascites was present; but pitting edema of the lower extremities was minimal. $\mathrm{He}$ received a regular diet, and on $3 / 18 / 48,2 \mathrm{cc}$. of mercupurin were given.

Case 4, R. $P$. An 82-year-old white male entered the hospital from the infirmary for the first time on $4 / 28 / 48$ because of dyspnea of several weeks' duration. When the experiment was performed the following day, physical examination revealed a pulse of 96 , a blood pressure of $210 / 100$, and a respiratory rate of 28 . Râles were present at both lung bases. An X-ray of the chest revealed left ventricular enlargement with pulmonary congestion. The second aortic sound was accentuated; no murmurs were heard. An electrocardiogram showed myocardial disease and left axis deviation. There was pitting edema of the lower extremities. The diet was regular. He had not received treatment for cardiac failure.

Case 5, F. B. A 76-year-old white male entered the hospital from the infirmary on $2 / 28 / 48$ with dyspnea of two months' duration. On the day of the experimental study, 3/1/48, physical examination revealed a pulse of 84 , a blood pressure of $160 / 95$, and a respiratory rate of 20. The eyegrounds showed evidence of arteriosclerosis. The radial and brachial arteries were thick and tortuous. Râles were present at both lung bases. The chest was emphysematous, and the heart sounds were faint. No murmurs were heard. A chest film revealed cardiac enlargement, the aorta was elongated and tortuous, and calcification was noted in the aortic knob. An electrocardiogram showed auricular fibrillation, left bundle branch block, myocardial disease, and left axis deviation. The lower extremities were markedly edematous. $\mathrm{He}$ had been on a regular diet and had not received therapy for cardiac failure.

Case 6, B. S., The patient was a 76-year-old white male who had been in the chronic hospital for several months with mild cardiac decompensation. When renal function studies were performed on $3 / 4 / 48$, physical examination revealed a pulse of 80 , a blood pressure of $160 / 60$, and a respiratory rate of 20 . The eyegrounds showed evidence of arteriosclerosis. Localized plaques were palpable in the radial arteries. Râles were present at both lung bases. The heart was enlarged to the left anterior axillary line. A loud systolic murmur was heard over the entire precordium, and an aortic diastolic murmur was transmitted to the apex. An electrocardiogram showed right atypical bundle branch block, myocardial disease, and ventricular premature contractions. There was pitting pedal edema. The serologic test for

TABLE I

(Experiments I and II)

The effect of theophylline ethylene diamine on renal function in control subjects

\begin{tabular}{|c|c|c|c|c|c|c|c|c|c|c|}
\hline & & \multicolumn{4}{|c|}{ Control periods } & \multicolumn{5}{|c|}{$\begin{array}{l}\text { Periods during or after administration } \\
\text { of theophylline ethylene diamine }\end{array}$} \\
\hline & & 1 & 2 & 3 & Average & 4 & 5 & 6 & 7 & 8 \\
\hline $\begin{array}{c}\text { Glomerular Filtration Rate } \\
c c . / \min . / 1.73 \text { sq.m. }\end{array}$ & $\begin{array}{l}\mathrm{A}^{*} \\
\mathrm{~B} \dagger\end{array}$ & $\begin{array}{l}87.3 \\
81.7\end{array}$ & $\begin{array}{l}91.9 \\
87.2\end{array}$ & $\begin{array}{l}84.7 \\
82.3\end{array}$ & $\begin{array}{l}87.2 \\
83.7\end{array}$ & $\begin{array}{l}101.0 \\
107.9\end{array}$ & $\begin{array}{r}104.9 \\
99.6\end{array}$ & $\begin{array}{r}102.8 \\
99.3\end{array}$ & $\begin{array}{r}99.1 \\
103.0\end{array}$ & $\begin{array}{r}100.8 \\
98.7\end{array}$ \\
\hline $\begin{array}{l}\text { Effective Renal Plasma Flow } \\
c c . / \text { min. } / 1.73 \text { sq.m. }\end{array}$ & $\underset{\mathbf{B}}{\mathbf{A}}$ & $\begin{array}{l}403.7 \\
371.3\end{array}$ & $\begin{array}{l}422.1 \\
387.0\end{array}$ & $\begin{array}{l}393.6 \\
376.4\end{array}$ & $\begin{array}{l}405.0 \\
378.2\end{array}$ & $\begin{array}{l}436.8 \\
503.9\end{array}$ & $\begin{array}{l}428.0 \\
421.6\end{array}$ & $\begin{array}{l}417.9 \\
398.4\end{array}$ & $\begin{array}{l}397.4 \\
435.1\end{array}$ & $\begin{array}{l}400.1 \\
407.7\end{array}$ \\
\hline $\begin{array}{l}\text { Filtration Fraction } \\
\text { per cent }\end{array}$ & $\begin{array}{l}\text { A } \\
\text { B }\end{array}$ & $\begin{array}{l}22.0 \\
22.2\end{array}$ & $\begin{array}{l}22.2 \\
23.0\end{array}$ & $\begin{array}{l}21.6 \\
22.1\end{array}$ & $\begin{array}{l}21.8 \\
22.5\end{array}$ & $\begin{array}{l}23.4 \\
21.9\end{array}$ & $\begin{array}{l}24.8 \\
24.1\end{array}$ & $\begin{array}{l}24.9 \\
25.7\end{array}$ & $\begin{array}{l}25.3 \\
23.9\end{array}$ & $\begin{array}{l}25.4 \\
24.5\end{array}$ \\
\hline $\begin{array}{l}\text { Urine Flow } \\
\qquad c c . / \min . / s q . m .\end{array}$ & $\begin{array}{l}\text { A } \\
\mathbf{B}\end{array}$ & $\begin{array}{l}1.72 \\
2.39\end{array}$ & $\begin{array}{l}2.60 \\
2.73\end{array}$ & $\begin{array}{l}2.51 \\
2.66\end{array}$ & $\begin{array}{l}2.41 \\
2.59\end{array}$ & $\begin{array}{l}7.38 \\
9.15\end{array}$ & $\begin{array}{l}5.74 \\
7.31\end{array}$ & $\begin{array}{l}5.44 \\
5.38\end{array}$ & $\begin{array}{l}4.78 \\
5.36\end{array}$ & $\begin{array}{l}4.24 \\
4.39\end{array}$ \\
\hline $\begin{array}{l}\text { Sodium Excretion } \\
\text { m.eq./min. }\end{array}$ & B & .266 & .291 & .280 & .279 & 1.016 & 1.070 & .880 & .928 & .819 \\
\hline
\end{tabular}

* A. Single dose of $0.48 \mathrm{gm}$. T.E.D.; urine collections interrupted during injection. (Mean values for nine subjects.) $\dagger$ B. $0.48 \mathrm{gm}$. T.E.D. injected during first five minutes of period $4 ; 0.48 \mathrm{gm}$. T.E.D. infused during remainder of experiment. (Mean values for six subjects.) 
TABLE II

(Experiment III)

The effect of a single injection of theophylline ethylene diamine on renal function in control subjects $(N=10)$

\begin{tabular}{|c|c|c|c|c|c|c|c|c|c|c|}
\hline \multirow{2}{*}{. } & & \multicolumn{4}{|c|}{ Control periods } & \multicolumn{5}{|c|}{$\begin{array}{l}\text { Periods after administration of } \\
\text { theophylline ethylene diamine }\end{array}$} \\
\hline & & 1 & 2 & 3 & Average & $4^{*}$ & 5 & 6 & 7 & 8 \\
\hline $\begin{array}{c}\text { Glomerular Filtration Rate } \\
c c . / \text { min. } / 1.73 \text { sq.m. }\end{array}$ & $\begin{array}{l}\mathrm{Mn} \\
\sigma_{\mathrm{Mn}}\end{array}$ & $\begin{array}{l}97.1 \\
6.6\end{array}$ & $\begin{array}{r}98.4 \\
6.1\end{array}$ & $\begin{array}{r}94.3 \\
6.8\end{array}$ & $\begin{array}{r}96.6 \\
6.1\end{array}$ & $\begin{array}{r}119.4 \\
7.2\end{array}$ & $\begin{array}{r}102.9 \\
6.5\end{array}$ & $\begin{array}{r}105.9 \\
7.4\end{array}$ & $\begin{array}{r}107.4 \\
6.4\end{array}$ & $\begin{array}{r}106.1 \\
6.4\end{array}$ \\
\hline $\begin{array}{l}\text { Effective Renal Plasma Flow } \\
c c . / \text { min. } / 1.73 \text { sq.m. }\end{array}$ & $\begin{array}{l}\mathrm{Mn} \\
\sigma_{\mathbf{M n}}\end{array}$ & $\begin{array}{r}469.6 \\
46.6\end{array}$ & $\begin{array}{r}481.7 \\
37.2\end{array}$ & $\begin{array}{r}472.4 \\
43.0\end{array}$ & $\begin{array}{r}474.6 \\
40.6\end{array}$ & $\begin{array}{r}618.9 \\
55.8\end{array}$ & $\begin{array}{r}475.5 \\
37.1\end{array}$ & $\begin{array}{r}470.7 \\
40.4\end{array}$ & $\begin{array}{r}455.9 \\
38.5\end{array}$ & $\begin{array}{r}462.2 \\
40.4\end{array}$ \\
\hline $\begin{array}{l}\text { Filtration Fraction } \\
\text { per cent }\end{array}$ & $\begin{array}{l}M n \\
\sigma_{M n}\end{array}$ & $\begin{array}{r}21.4 \\
1.1\end{array}$ & $\begin{array}{r}20.9 \\
0.8\end{array}$ & $\begin{array}{r}20.4 \\
0.9\end{array}$ & $\begin{array}{r}20.9 \\
0.9\end{array}$ & $\begin{array}{r}19.9 \\
1.1\end{array}$ & $\begin{array}{r}22.0 \\
0.9\end{array}$ & $\begin{array}{r}23.0 \\
0.8\end{array}$ & $\begin{array}{r}24.2 \\
1.1\end{array}$ & $\begin{array}{r}23.6 \\
1.0\end{array}$ \\
\hline $\begin{array}{l}\text { Urine Flow } \\
\qquad c c . / \min . / s q . m .\end{array}$ & $\begin{array}{l}\mathrm{Mn} \\
\sigma_{\mathbf{M n}}\end{array}$ & $\begin{array}{c}2.32 \\
.5\end{array}$ & $\begin{array}{c}2.62 \\
.4\end{array}$ & $\begin{array}{l}2.59 \\
.4\end{array}$ & $\begin{array}{c}2.51 \\
.4\end{array}$ & $\begin{array}{l}8.20 \\
1.0\end{array}$ & $\begin{array}{c}5.19 \\
.5\end{array}$ & $\begin{array}{c}3.88 \\
.6\end{array}$ & $\begin{array}{c}3.44 \\
.3\end{array}$ & $\begin{array}{c}3.16 \\
.4\end{array}$ \\
\hline $\begin{array}{l}\text { Sodium Clearance } \\
c c . / \min .\end{array}$ & $\begin{array}{l}M n \\
\sigma_{M_{n}}\end{array}$ & $\begin{array}{r}2.26 \\
.25\end{array}$ & $\begin{array}{r}2.33 \\
.21\end{array}$ & $\begin{array}{r}2.25 \\
.26\end{array}$ & $\begin{array}{r}2.28 \\
.23\end{array}$ & $\begin{array}{r}7.32 \\
.78\end{array}$ & $\begin{array}{r}6.88 \\
.48\end{array}$ & $\begin{array}{r}6.35 \\
.49\end{array}$ & $\begin{array}{r}6.61 \\
.59\end{array}$ & $\begin{array}{r}6.03 \\
.40\end{array}$ \\
\hline $\begin{array}{l}\text { Concentration of Sodium in Urine } \\
m . e q . / c c .\end{array}$ & $\begin{array}{l}M n \\
\sigma_{M n}\end{array}$ & $\begin{array}{l}.089 \\
.018\end{array}$ & $\begin{array}{l}.087 \\
.014\end{array}$ & $\begin{array}{l}.081 \\
.014\end{array}$ & $\begin{array}{l}.086 \\
.014\end{array}$ & $\begin{array}{l}.075 \\
.006\end{array}$ & $\begin{array}{l}.114 \\
.012\end{array}$ & $\begin{array}{l}.153 \\
.022\end{array}$ & $\begin{array}{l}.159 \\
.014\end{array}$ & $\begin{array}{l}.170 \\
.019\end{array}$ \\
\hline
\end{tabular}

* Injection of $0.48 \mathrm{gm}$. of drug during the first five minutes of the fourth clearance period

syphilis was positive. Treatment had consisted of 2 cc. of mercupurin weekly; no digitalis was taken. His last injection of mercupurin had been on $2 / 27 / 48$. His diet was regular.

\section{Experimental procedure}

The test was begun after a 12-hour fast at 8:00 a.m., and three control clearance periods were usually completed by $9: 30$ a.m. Each subject was given $100 \mathrm{cc}$. of water at 6:00 a.m., and every one-half hour thereafter until the control periods had been completed. Filtration rate and effective renal plasma flow were measured by inulin and diodrast clearance respectively (13). All tests were made at constant blood levels of inulin and diodrast, using an infusion rate of 3.0 cc. per minute. Urine samples were collected by catheterization over 10-12 minute periods.

Venous pressure was measured by the method of Moritz and von Tabora and was referred to a point $10 \mathrm{~cm}$. from the back at the level of the fourth intercostal space adjacent to the sternum.

\section{Experimental Design-Control Subjects}

A preliminary study (Experiments I and II) was conducted to determine a satisfactory time schedule and dose of intravenous T.E.D. Experiment III served as the control series for the study of patients in cardiac failure.

Experiment I. The effect of a single injection of T.E.D. on renal function with interruption of clearance periods during the injection. At the completion of three control clearance periods of 10-12 minutes each, $0.48 \mathrm{gm}$. of T.E.D. was administered intravenously over a period of five minutes. At the end of the injection, the bladder was washed, and five more clearance periods were fol- lowed. Only inulin and diodrast clearances were determined in the nine subjects of this experiment.

Experiment II. The effect of the continuous administration of T.E.D. on renal function. In order to increase the magnitude of the effect, a larger dose ( 0.96 $\mathrm{gm}$.) of the drug was given in this experiment. A single injection of $0.48 \mathrm{gm}$. of T.E.D. was administered intravenously during the first five minutes of period 4 and another $0.48 \mathrm{gm}$. was infused with the inulin and diodrast solution during the remaining five clearance periods. In this group of six subjects, sodium excretion was studied in addition to the clearance of inulin and diodrast.

Experiment III. The effect of a single injection of T.E.D. on renal function without interruption of the clearance periods during the injection. On the basis of the results of Experiments I and II, a single injection of $0.48 \mathrm{gm}$. of T.E.D. was made during the first five minutes of clearance period 4 in ten subjects. Inulin, diodrast, and sodium clearances were determined.

\section{Experimental Design-Patients in Congestive Heart Failure}

Experiment IV. The same time schedule and dose of T.E.D. as in Experiment III (control group) were used in the study of the six patients in heart failure.

\section{Chemical Methods}

Inulin analyses were made according to the method of Harrison (14). A modification of the method of Flox, Pitesky, and Alving (15) was used in the determination of diodrast iodine (16). It was demonstrated that T.E.D. did not interfere with the chemical recovery of inulin and diodrast iodine from human plasma. So- 
dium was determined gravimetrically according to the method of Butler and Tuthill (17).

\section{RESULTS}

\section{Control subjects}

\section{(Experiments I, II, III)}

Glomerular filtration rate. Administration of T.E.D. was followed by a sustained elevation of the glomerular filtration rate which persisted for 55-60 minutes in the control subjects (Tables I and II) (average control period-period 8; $\mathrm{t}=$ 3.64, $\mathrm{P}<1 \%, \mathrm{~N}=10^{3}$ for Experiment III). The magnitude of the rise varied with the dose of T.E.D. so that the greatest increase occurred with the continuous infusion of $0.96 \mathrm{gm}$. (Experiment II).

Effective renal plasma flow. The response of effective renal plasma flow to T.E.D. was variable. In some cases, a transitory rise was observed during the fourth clearance period only; during the remaining periods effective renal plasma flow was at a control level or below. In other subjects, renal plasma flow increased during the fourth clearance period and gradually returned to the control value during periods $5-8$. The average change for 10 subjects (Experiment III) was an elevation during the fourth period only (Table II, Figure 1) (average control period-period $4 ; \mathrm{t}=5.64, \mathrm{P}<$ $1 \%, \mathrm{~N}=10$ ) (average control period-period 8; $\mathrm{t}=.78, \mathrm{P}>90 \%, \mathrm{~N}=10)$. After continuous infusion of $0.96 \mathrm{gm}$. of T.E.D., the elevation in effective renal plasma flow was consistently maintained for a longer period than after a single injection.

Filtration fraction. The average filtration fraction remained unchanged during the fourth and fifth clearance periods but increased significantly

${ }^{3}$ Since all values obtained before and after the administration of T.E.D. in a given subject are highly correlated, all tests for significances were made by calculating $\mathrm{t}$ scores by the difference method.

$$
\begin{aligned}
& t=\frac{\frac{\Sigma\left(x_{1}-x_{2}\right)}{N}}{\sigma_{M_{n} \text { diff. }}}=\frac{M n \text { diff. }}{\sigma_{M n \text { diff. }}} \\
& \sigma_{\mathrm{Mn} \text { diff. }}=\frac{\sigma_{\text {diff. }}}{\sqrt{\mathrm{N}-1}} \\
& \sigma_{\text {diff. }}=\sqrt{\frac{\sum\left(x_{1}-x_{2}\right)^{2}}{N}-\left(\frac{\sum\left(x_{1}-x_{2}\right)}{N}\right)^{2}}
\end{aligned}
$$

where $x_{1}$ and $x_{2}$ are observations made before and after treatment in the same subject. in the remaining three periods $(6-8)$ (average control period-period $5 ; \mathrm{t}=1.34, \mathrm{P}=90 \%, \mathrm{~N}$ $=10$ ) (average control period-period 8; $\mathrm{t}=$ $5.15, \mathrm{P}<1 \%, \mathrm{~N}=10$ ). Wide individual differences in response were observed.

Urine flow. Average urine flow increased threefold immediately after the administration of T.E.D. (average control period-period $4 ; \mathrm{t}=6.62, \mathrm{P}<$ $1 \%, \mathrm{~N}=10$ ) and gradually returned to a level slightly above the control values in the remaining periods (average control period-period $5 ; \mathrm{t}=$ 4.77, $\mathrm{P}<1 \%, \mathrm{~N}=10$ ) (average control-period $8 ; \mathrm{t}=1.44, \mathrm{P}=80-90 \%, \mathrm{~N}=10$ ).

Sodium clearance. The average sodium clearance (Experiment III) increased approximately threefold for 55-60 minutes after the administration of T.E.D. (average control period-period 4; $\mathrm{t}=6.72, \mathrm{P}<1 \%, \mathrm{~N}=10$ ) (average control period-period $8 ; \mathrm{t}=8.72, \mathrm{P}<1 \%, \mathrm{~N}=10)$. The mean plasma sodium values for the 10 cases were $139.7,139.1,139.5,138.3,138.8,137.9,139.2$, and 137.9 m.eq./L. for clearance periods $1-8$ respectively. The difference between the average control value for plasma sodium and the average for the five periods after the injection of T.E.D. was insignificant $(t=2.58, P=4 \%, N=10)$. The concentration of sodium in the urine remained unchanged during the fourth clearance period but increased gradually during the remaining periods until it doubled the control value (average control period-period $4 ; \mathrm{t}=0.70, \mathrm{P}>90 \%, \mathrm{~N}=$ 10) (average control period-period $8 ; t=3.65$, $\mathrm{P}<1 \%, \mathrm{~N}=10)$.

Venous pressure. Venous pressure decreased from a mean control value of 10.0 to $8.3 \mathrm{~cm}$. of saline after the administration of T.E.D. $(t=$ $9.08, \mathrm{P}<1 \%, \mathrm{~N}=10$ ).

\section{Patients in congestive heart failure \\ (Experiment IV)}

The six cases in this experiment included two patients with inactive rheumatic valvular disease, two with arteriosclerotic heart disease, one with hypertensive cardiovascular disease, and one with syphilitic and arteriosclerotic heart disease. The findings from the study of two of these cases which illustrate the variation in the control values and the response in renal function to T.E.D. are compared with the average values for the control 
group (Experiment III) in Figure 1. The results for the entire group are summarized in Table III.

Control periods. The mean values for the three control clearance periods for filtration rate varied from normal to more than $50 \%$ below normal. Effective renal plasma flow was reduced below $300 \mathrm{cc} . / \mathrm{min} . / 1.73 \mathrm{sq} . \mathrm{m}$. in all cases. Filtration fraction was elevated in all but Case 6 . Sodium clearance was reduced considerably below the mean value for the control group $(2.28 \mathrm{cc}$. $/ \mathrm{min}$. \pm .23 ) in Cases $1-4$ but was elevated in Cases 5 and 6. Attention is called to the fact that a low sodium clearance was present in cases with a normal filtration rate while the cases with an elevated sodium clearance showed a low filtration rate. Urine flow was diminished below the average control level in all but Case 5. The concentration of sodium in urine was lower than the average control level in all but Case 6 .

Periods after the administration of T.E.D. The response in renal hemodynamics and sodium excretion to this drug was variable both in magnitude and duration. The elevated filtration rate was not sustained throughout the experiment in a single case and was increased for one period only

TABLE III

(Experiment IV)

The effect of theophylline ethylene diamine on renal function in patients with cardiac failure

\begin{tabular}{|c|c|c|c|c|c|c|c|c|c|c|}
\hline \multirow{2}{*}{$\begin{array}{l}\text { Case } \\
\text { No. }\end{array}$} & & \multicolumn{4}{|c|}{ Control periods } & \multicolumn{5}{|c|}{$\begin{array}{l}\text { Periods after administration of } \\
\text { theophylline ethylene diamine }\end{array}$} \\
\hline & & 1 & 2 & 3 & Average & $4^{*}$ & 5 & 6 & 7 & 8 \\
\hline $\begin{array}{l}1 \\
2 \\
3 \\
4 \\
5 \\
6\end{array}$ & $\begin{array}{l}\text { Glomerular Filtration Rate } \\
c c . / \text { min:/1.73 sq.m. }\end{array}$ & $\begin{array}{r}92.4 \\
98.5 \\
131.2 \\
75.4 \\
59.9 \\
27.6\end{array}$ & $\begin{array}{r}99.8 \\
97.2 \\
140.0 \\
70.8 \\
58.6 \\
30.0\end{array}$ & \begin{tabular}{|r}
108.1 \\
98.4 \\
132.3 \\
58.9 \\
57.1 \\
25.8
\end{tabular} & $\begin{array}{r}100.1 \\
98.0 \\
134.5 \\
68.4 \\
58.5 \\
27.8\end{array}$ & $\begin{array}{r}239.1 \\
143.1 \\
143.0 \\
69.8 \\
72.1 \\
31.6\end{array}$ & \begin{tabular}{|r}
94.6 \\
113.8 \\
125.6 \\
75.2 \\
54.4 \\
23.2
\end{tabular} & $\begin{array}{r}102.4 \\
136.3 \\
121.7 \\
74.5 \\
61.5 \\
24.7\end{array}$ & $\begin{array}{r}89.5 \\
107.8 \\
119.2 \\
- \\
60.5 \\
25.3\end{array}$ & $\begin{array}{r}106.0 \\
85.8 \\
123.7 \\
-\overline{65.5} \\
26.0\end{array}$ \\
\hline $\begin{array}{l}1 \\
2 \\
3 \\
4 \\
5 \\
6\end{array}$ & $\begin{array}{l}\text { Effective Renal Plasma Flow } \\
c c . / \min . / 1.73 \mathrm{sq.m} .\end{array}$ & $\begin{array}{l}154.0 \\
217.6 \\
272.6 \\
199.0 \\
198.6 \\
137.9\end{array}$ & $\begin{array}{l}186.1 \\
214.0 \\
295.2 \\
183.4 \\
170.1 \\
128.8\end{array}$ & \begin{tabular}{|l}
192.0 \\
209.2 \\
275.7 \\
154.7 \\
167.9 \\
131.4
\end{tabular} & $\begin{array}{l}177.4 \\
213.6 \\
281.6 \\
179.3 \\
178.8 \\
132.7\end{array}$ & $\begin{array}{l}388.0 \\
359.1 \\
382.0 \\
185.3 \\
218.1 \\
163.0\end{array}$ & $\begin{array}{l}185.0 \\
266.6 \\
329.0 \\
164.2 \\
197.1 \\
130.3\end{array}$ & $\begin{array}{l}194.7 \\
283.7 \\
271.3 \\
153.8 \\
201.8 \\
131.9\end{array}$ & $\begin{array}{r}155.1 \\
256.0 \\
307.8 \\
202.5 \\
127.9\end{array}$ & $\begin{array}{r}195.2 \\
208.4 \\
324.0 \\
-\overline{193.9} \\
141.3\end{array}$ \\
\hline $\begin{array}{l}1 \\
2 \\
3 \\
4 \\
5 \\
6\end{array}$ & $\begin{array}{l}\text { Filtration Fraction } \\
\text { per cent }\end{array}$ & $\begin{array}{l}60.0 \\
45.3 \\
48.1 \\
37.9 \\
30.1 \\
20.0\end{array}$ & $\begin{array}{l}53.6 \\
45.4 \\
47.4 \\
38.6 \\
34.4 \\
23.3\end{array}$ & $\begin{array}{l}56.3 \\
47.0 \\
48.0 \\
38.0 \\
34.0 \\
19.7\end{array}$ & $\begin{array}{l}56.6 \\
45.9 \\
47.8 \\
38.2 \\
32.8 \\
21.0\end{array}$ & $\begin{array}{l}61.6 \\
39.8 \\
37.4 \\
37.7 \\
33.0 \\
19.4\end{array}$ & $\begin{array}{l}51.1 \\
42.7 \\
38.2 \\
45.8 \\
27.6 \\
17.8\end{array}$ & $\begin{array}{l}52.6 \\
48.0 \\
44.9 \\
48.4 \\
30.5 \\
18.5\end{array}$ & $\begin{array}{r}57.7 \\
42.1 \\
38.7 \\
- \\
29.9 \\
19.8\end{array}$ & $\begin{array}{l}54.3 \\
41.2 \\
38.2 \\
33.8 \\
18.4\end{array}$ \\
\hline $\begin{array}{l}1 \\
2 \\
3 \\
4 \\
5 \\
6\end{array}$ & $\begin{array}{l}\text { Urine Flow } \\
\qquad c . / \text { min./sq.m. }\end{array}$ & $\begin{array}{l}2.45 \\
- \\
1.74 \\
5.42 \\
1.61\end{array}$ & $\begin{array}{r}1.59 \\
.34 \\
1.22 \\
1.60 \\
6.68 \\
1.47\end{array}$ & $\begin{array}{r}1.49 \\
.28 \\
.51 \\
1.16 \\
5.42 \\
2.30\end{array}$ & $\begin{array}{r}1.84 \\
.21 \\
.58 \\
1.50 \\
5.84 \\
1.79\end{array}$ & $\begin{array}{r}6.63 \\
1.80 \\
5.99 \\
2.22 \\
11.12 \\
3.17\end{array}$ & $\begin{array}{l}4.73 \\
1.65 \\
7.65 \\
2.46 \\
5.60 \\
2.24\end{array}$ & $\begin{array}{l}3.54 \\
2.72 \\
5.09 \\
1.89 \\
4.12 \\
1.70\end{array}$ & $\begin{array}{r}3.66 \\
1.74 \\
4.75 \\
- \\
5.36 \\
.90\end{array}$ & $\begin{array}{r}3.06 \\
2.01 \\
5.23 \\
4.82 \\
.94\end{array}$ \\
\hline $\begin{array}{l}1 \\
2 \\
3 \\
4 \\
5 \\
6\end{array}$ & $\begin{array}{l}\text { Sodium Clearance } \\
c c . / \min .\end{array}$ & $\begin{array}{r}.50 \\
.14 \\
.41 \\
1.53 \\
4.10 \\
2.69\end{array}$ & $\begin{array}{r}.53 \\
.14 \\
.41 \\
1.28 \\
5.13 \\
2.67\end{array}$ & $\begin{array}{r}.58 \\
.14 \\
.37 \\
1.16 \\
4.69 \\
2.59\end{array}$ & $\begin{array}{r}.53 \\
.14 \\
.40 \\
1.32 \\
4.64 \\
2.65\end{array}$ & $\begin{array}{l}4.80 \\
2.82 \\
7.36 \\
3.78 \\
6.78 \\
3.82\end{array}$ & $\begin{array}{l}3.06 \\
3.29 \\
9.34 \\
4.14 \\
4.90 \\
2.98\end{array}$ & $\begin{array}{l}2.81 \\
3.55 \\
6.65 \\
4.10 \\
4.85 \\
2.30\end{array}$ & $\begin{array}{l}2.52 \\
3.39 \\
6.45 \\
- \\
4.59 \\
2.17\end{array}$ & $\begin{array}{l}2.77 \\
2.90 \\
6.68 \\
\overline{5.65} \\
1.98\end{array}$ \\
\hline $\begin{array}{l}1 \\
2 \\
3 \\
4 \\
5 \\
6\end{array}$ & $\begin{array}{l}\text { Concentration of Sodium in Urine } \\
\text { m.eq./cc. }\end{array}$ & $\begin{array}{l}.019 \\
- \\
.063 \\
.064 \\
.132\end{array}$ & $\begin{array}{l}.031 \\
.036 \\
.031 \\
.058 \\
.065 \\
.145\end{array}$ & $\begin{array}{l}.036 \\
.043 \\
.068 \\
.072 \\
.073 \\
.089\end{array}$ & $\begin{array}{l}.028 \\
.029 \\
.033 \\
.064 \\
.067 \\
.123\end{array}$ & $\begin{array}{l}.066 \\
.138 \\
.115 \\
.121 \\
.052 \\
.095\end{array}$ & $\begin{array}{l}.059 \\
.176 \\
.114 \\
.120 \\
.074 \\
.106\end{array}$ & $\begin{array}{l}.073 \\
.113 \\
.122 \\
.154 \\
.099 \\
.108\end{array}$ & $\begin{array}{c}.063 \\
.172 \\
.127 \\
-\quad 072 \\
.193\end{array}$ & $\begin{array}{l}.083 \\
.127 \\
.120 \\
.099 \\
.167\end{array}$ \\
\hline
\end{tabular}

* Injection of $\mathbf{0 . 4 8} \mathbf{g m}$. of drug during the first five minutes of the fourth clearance period 


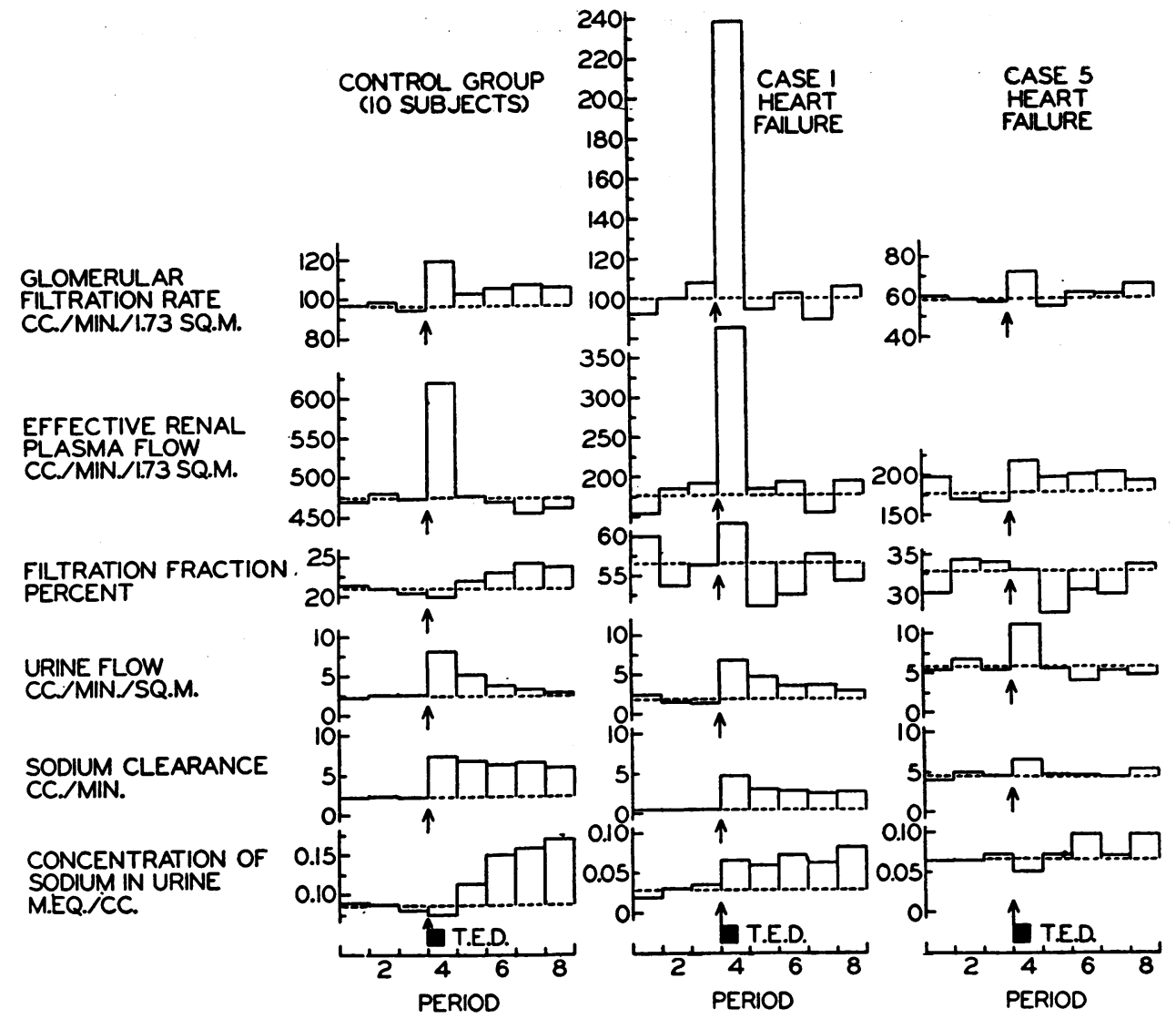

Fig. 1. The Effect of Theophylline Ethylene Diamine on Renal Function in a Group of 10 Control Subjects (Experiment III) and in Two Patients with Congestive Heart Failure (Experiment IV)

Case 1 with heart failure showed a normal filtration rate but sodium clearance was low during the control periods; a maximal response to T.E.D. occurred. Case 5 with heart failure showed a low filtration rate but an elevated sodium clearance was obtained during the control periods; a minimal response to T.E.D. occurred. The arrows indicate the time of the beginning of the injection of T.E.D. The dotted line represents the mean value for the three periods before T.E.D.

in two of the three cases in which a significant response occurred. The rise in effective renal plasma flow was also transitory. The increase in sodium and water excretion varied from a moderate elevation in Case 4 to a marked rise in Cases 1 and 3 . As in the control study (Experiment III) the elevation in sodium clearance was sustained for five clearance periods in Cases $1-4$ but was increased during period 4 only in Cases 5 and 6 . The water diuresis was maintained throughout the experiment in Cases 1-4 as compared with the more transitory diuresis in the controls. The concentration of sodium in the urine increased after T.E.D. in Cases 1-4 and remained at the elevated level in accordance with the sustained in- crease in both urine flow and sodium clearance. In Cases 5 and 6 the changes in the concentration of sodium in the urine were insignificant.

\section{DISCUSSION}

\section{Mechanism of xanthine diuresis}

Studies of the diuretic action of xanthines have yielded conflicting findings both in lower animals and man. As a result, two principal theories have been formulated to explain the mechanism of xanthine diuresis. First, it has been proposed that diuresis is primarily the result of augmented glomerular filtration rate secondary to an increase in renal blood flow. Secondly, investigators have 
presented evidence that xanthines exert their action on the renal tubules to decrease reabsorption of water and electrolytes.

Effect of xanthines on renal hemodynamics. In lower animals, some xanthines increase filtration rate, while others do not. For instance, Schmitz (18) reported that euphyllin consistently increased glomerular filtration rate in dogs while others (19-21) found renal hemodynamics unaltered significantly after the injection of theophylline in rabbits and dogs.

In man the results have been more uniform. With the exception of an early report by Blumgart and associates (22), studies (11, 23-27) have demonstrated repeatedly an alteration in renal hemodynamics. However, there is considerable variation in the magnitude and duration of the response.

In the present study, a sustained increase in glomerular filtration rate occurred consistently in the 25 control subjects while the response in patients with congestive heart failure was variable. In normal subjects, Howarth and associates (28) reported a $35 \%$ increase in cardiac output which lasted for 10-15 minutes after the intravenous administration of $0.48 \mathrm{gm}$. of T.E.D. Consequently, the sustained elevation in glomerular filtration in control subjects may be explained on the basis of renal arteriolar dilatation, while the marked initial response in Experiments II and III may be the result of a transitory elevation in cardiac output superimposed upon alterations in the renal arterioles. The more transitory response in filtration rate in patients with cardiac failure suggests that T.E.D. has less effect upon the renal arterioles in these patients than in controls. Furthermore, the marked immediate elevation and transitory response in glomerular filtration in some cases with cardiac failure (Cases 1 and 2) may be primarily the result of increased cardiac output rather than renal arteriolar dilatation.

Since most of the control values of renal plasma flow in elderly subjects are low when compared with the values reported for the middle and young age groups $(16,29)$, the question arises as to the completeness of renal diodrast extraction. From the available data this question cannot be answered and renal plasma flow has been referred to as "ef- fective renal plasma flow." An increase in diodrast clearance may be indicative of an increase in renal plasma flow after the administration of T.E.D. unless the renal diodrast extraction ratio is increased by improving the cellular function of the tubules so that they extract a higher percentage of diodrast. The changes in effective renal plasma flow may then be attributed to possible alterations in (1) cardiac output, (2) afferent and efferent arteriolar size, and (3) diodrast extraction.

Effect of T.E.D. on tubular reabsorption. Consideration of the temporal relationship of the response in filtration rate to the rise in sodium clearance reveals that both were sustained for 50-60 min. in the control subjects. However, Cases $1-4$ with congestive heart failure showed a very transitory or no increase in filtration rate while sodium clearance was maintained at an elevated level throughout the experiment. This finding that T.E.D. decreases sodium reabsorption was presented in a preliminary report by Davis and Shock (27) and confirmed by Sinclair-Smith and associates (11).

Evidence that T.E.D. results in decreased water reabsorption is suggested from the relationship of the level of filtration rate to urine flow in the control subjects. The elevated filtration rate was maintained for five periods after T.E.D. but urine flow returned to the control level during periods 7 and 8 (Figure 1). Since the tubules possess the capacity to reabsorb the increased load of water imposed by the elevated filtration rate during periods 7 and 8 , the increase in urine flow during periods 4-6 may be explained on the basis of T.E.D. inhibiting water reabsorption. ${ }^{4}$ Furthermore, urine flow was maintained at an elevated level in cases of cardiac failure in whom the response in filtration rate was transitory. These findings indicate that the sustained diuretic effect of T.E.D. is primarily the result of its action (direct or indirect through the posterior pituitary) on renal tubules. The lack of an elevated urine flow in the presence of a high sodium clearance (periods 7-8) indicates that this level of sodium excretion was insufficient to effect an appreciable osmotic diuresis.

4 This assumes that $T_{m}$ for water remains constant for periods 4-8. For a discussion of $T_{m}$ for water see Wesson, Anslow, and Smith (12). 


\section{Renal Function in Congestive Heart Failure}

Clearance determinations during the control periods revealed a normal glomerular filtration rate in the presence of a low sodium clearance in Cases 1-4. In Case 4, the glomerular filtration rate of $68.4 \mathrm{cc} . / \mathrm{min} . / 1.73 \mathrm{sq} . \mathrm{m}$. may seem abnormally low for even an 82-year-old man, but this is the same order of magnitude as reported by Davies and Shock (29) for men 80-90 years of age who showed no evidence of cardiac or renal disease from history, physical examination and urinalysis. Cases 5 and 6 showed a low filtration rate but sodium clearance was higher than the mean value for the control group. These findings of the lack of correlation between the level of filtration rate and sodium clearance coincide with the results of other studies $(10,11,30)$ and indicate that filtration rate is not the primary mechanism for salt retention in cardiac failure.

The incidence of a normal filtration rate in onehalf to two-thirds of the patients with cardiac failure in this series may be unusually high. However, examination of the results of other investigators indicates that a normal filtration rate is not uncommon $(4,10,11,30)$. Farnsworth and Krakusin (30) reported one of two cases and Sinclair-Smith and associates (11) found one of three cases who consistently showed a normal filtration rate during long term electrolyte balance and renal function studies. Briggs and coworkers (10) noted a glomerular filtration rate above 105 cc./min./1.73 sq.m. in three of 16 cases. When account is taken of the decline in filtration rate with age (29), the per cent of reported cases with a normal glomerular filtration rate in a large series such as Merrill's becomes significant.

The two cases (5 and 6) who showed an elevated sodium clearance are unusual. Certain data suggest that they had intrinsic renal tubular disease before the onset of congestive heart failure. After the state of cardiac compensation had improved, concentration tests revealed a low maximal specific gravity of the urine (1.015 and 1.018). In both cases an advanced degree of generalized arteriosclerosis was present. Although it is not possible to predict the extent of renal involvement from the degree of arteriosclerosis in the peripheral vessels, arteriosclerosis would offer a likely explanation for such renal involvement. It seems unlikely that an elevated sodium intake was present in these two patients since they were on a diet similar to the control subjects and two of the patients with a low sodium clearance. Furthermore, the elevated sodium clearance was not the result of improvement during diuresis as described in some cases of Threefoot, Burch, and Reaser (31) because these patients were becoming progressively more decompensated before the experiment. It may be of some significance that the control subjects and patients in cardiac failure received normal saline in both the priming and sustaining solutions. Since they received approximately $3 \mathrm{cc}$. of normal saline per minute, $.426 \mathrm{~m} . e q . / \mathrm{min}$. of sodium chloride was infused. This value is of the same order of magnitude as the quantity of sodium excreted (.639 and $.366 \mathrm{~m} . \mathrm{eq} . / \mathrm{min}$. in Cases 5 and 6 respectively).

The experimental alteration of renal hemodynamics in heart failure by T.E.D. proved to be of little importance in studying the mechanism of salt and water retention. Since T.E.D. decreases tubular reabsorption of sodium, it tends to obscure any close correlation which might exist between sodium excretion and the tubular load of sodium. It should be pointed out, however, that an elevation in glomerular filtration rate was frequently unaccompanied by a corresponding increase in sodium clearance. In other words, the tubules were capable of reabsorbing approximately two and onehalf the tubular load of sodium during period 4 as compared with periods 5-8 (see Case 1).

Since the evidence presented in this study offers no support for the hypothesis that salt retention is the result of a low filtration rate, the theory that renal impairment in cardiac failure is related to tubular dysfunction should be investigated more thoroughly. A low filtration rate may lead to salt retention by increasing tubular reabsorption of sodium or by some other mechanism in some patients but in other cases the kidney retains sodium in the presence of a normal glomerular filtration rate. The exact mechanism responsible for the accumulation of salt and water in heart failure awaits a more complete understanding of the tubular reabsorptive mechanism of sodium in normal individuals. Investigation of the role of extra-renal factors such as extracellular fluid volume, adrenal cortical hormones, and the secretion of the posterior pituitary may help to clarify this complicated problem. 


\section{SUMMARY}

The effect of theophylline ethylene diamine on renal function was studied in 25 control subjects and in six patients with congestive heart failure. Venous pressure was measured in 10 of the control subjects and in four of the patients with cardiac failure.

In the control subjects, an increase in filtration rate was sustained for 50-60 minutes. The response in effective renal plasma flow varied from a transitory elevation lasting 10-12 minutes to an elevation followed by a gradual return to the control level or below. Filtration fraction was usually unchanged during the first two periods after T.E.D. but was elevated during the remaining three clearance periods. Urine flow trebled immediately after the injection of T.E.D. and gradually returned to a value slightly above the control level during the next 50 or 60 minutes. Sodium clearance increased threefold and remained elevated throughout the test. The concentration of sodium in the urine was unaltered immediately after the injection of T.E.D. but gradually increased to a level double the control. The mean decrease in venous pressure was 17 per cent of the control value.

During the three control periods the patients in congestive heart failure showed a filtration rate within normal limits in Cases 1-4 while effective renal plasma flow was consistently reduced. Urine flow was below the level for the control subjects in these four patients. In Cases 5 and 6, both filtration rate and effective renal plasma flow were greatly diminished. Urine flow was elevated in Case 5 but depressed in Case 6 . Filtration fraction was elevated in all but one of the six patients. The concentration of sodium in the urine was decreased below the value for the control group in all but one case.

The response in renal hemodynamics to T.E.D. in patients with cardiac failure was variable. Filtration rate and effective renal plasma flow failed to increase at all in some patients and increased over 100 per cent in others. In Cases 1-4 urine flow and sodium clearance varied from a slight to a marked response. In Cases 5 and 6 urine flow and sodium clearance increased slightly only immediately after the injection of T.E.D. The concentration of sodium in the urine increased immediately after T.E.D. in Cases $1-4$ but remained unchanged in Cases 5 and 6 except for a slight increase during the last clearance periods. The response in venous pressure to T.E.D. varied with the height of the initial level; in patients with a control tension of approximately $10.0 \mathrm{~cm}$. of saline the response was similar to that observed in control subjects while one patient with a high venous tension before T.E.D., showed a marked fall.

\section{CONCLUSIONS}

The mechanism of the diuretic action of T.E.D. in man is apparently two fold. An increase in the excretion of sodium and water is associated with (1) an elevation in glomerular filtration rate, and (2) a decrease in renal tubular reabsorption of sodium and water. Although a quantitative evaluation of the relative importance of each of these factors cannot be made from the available data, it seems that a decrease in tubular reabsorption contributes more to the sustained diuresis than augmented filtration rate.

The evidence from this study offers no support for the concept that salt and water retention by the kidney in patients with congestive heart failure is the result of low filtration rate. Consequently, it appears that the mechanism of renal impairment in cardiac failure is to be sought in a study of the tubular reabsorptive mechanism of sodium.

\section{BIBLIOGRAPHY}

1. Futcher, P. H., and Schroeder, H. A., Studies on congestive heart failure. II. Impaired renal excretion of sodium chloride. Am. J. M. Sc., 1942, 204, 52.

2. Warren, J. V., and Stead, E. A., Jr., Fluid dynamics in chronic congestive heart failure; interpretation of mechanisms producing edema, increased plasma volume and elevated venous pressure in certain patients with prolonged congestive failure. Arch. Int. Med., 1944, 73, 138.

3. Davis, J. O., and Smith, J. R., Pathogenesis of peripheral cardiac edema. Am. J. Med., 1947, 3, 704.

4. Merrill, A. J., Edema and decreased renal blood flow in patients with chronic congestive heart failure: evidence of "forward failure" as the primary cause of edema. J. Clin. Invest., 1946, 25, 389.

5. Mokotoff, R., Ross, G., and Leiter, L., Renal plasma flow and sodium reabsorption and excretion in congestive heart failure. J. Clin. Invest., 1948, 27, 1. 
6. Farnsworth, E. B., Clearance of inulin, diodrast, chloride, and phosphate under mercurial diuresis; intensive study of a patient in severe cardiac failure. Am. J. Med., 1946, 1, 246.

7. Farnsworth, E. B., Electrolyte partition in patients with edema of various origins. Am. J. Med., 1948, 4, 338.

8. Reaser, P. B., and Burch, G. E., Radiosodium tracer studies in congestive heart failure. Proc. Soc. Exper. Biol. \& Med., 1946, 63, 543.

9. Burch, G., Reaser, P., and Cronvich, J., Rates of sodium turnover in normal subjects and in patients with congestive heart failure. J. Lab. \& Clin. Med., 1947, 32, 1169.

10. Briggs, A. P., Fowell, D. M., Hamilton, W. F., Remington, J. W., Wheeler, N. C., and Winslow, J. A., Renal and circulatory factors in edema formation of congestive heart failure. J. Clin. Invest., 1948, 27, 810.

11. Sinclair-Smith, B., Kattus, A. A., Genest, J., and Newman, E. V., The renal mechanism of electrolyte excretion and metabolic balances of electrolytes and nitrogen in congestive heart failure: The effects of exercise, rest, and aminophylline. Bull. Johns Hopkins Hosp., 1949, 84, 369.

12. Wesson, L. G., Jr., Anslow, W. P., Jr., and Smith, H. W., The excretion of strong electrolytes. Bull. N. Y. Acad. Med., 1948, 24, 586.

13. Smith, H. W., Goldring, W., and Chasis, H., Measurement of the tubular excretory mass, effective blood flow and filtration rate in the normal human kidney. J. Clin. Invest., 1938, 17, 263.

14. Harrison, H. E., A modification of the diphenylamine method for determination of inulin. Proc. Soc. Exp. Biol. \& Med., 1942, 49, 111.

15. Flox, J., Pitesky, I., and Alving, A. S., A direct photoelectric colorimetric method for the determination of diodrast and iodides in blood and urine. J. Biol. Chem., 1942, 142, 147.

16. Shock, N. W., Kidney function tests in aged males. Geriatrics, 1946, 1, 232.

17. Butler, A. M., and Tuthill, E., An application of the uranyl zinc acetate method for the determination of sodium in biological material. J. Biol. Chem., 1931, 93, 171.

18. Schmitz, H. L., Studies on the action of diuretics. I. The effect of euphyllin and salyrgan upon glomerular filtration and tubular reabsorption. J. Clin. Invest., 1932, 11, 1075.

19. Walker, A. M., Schmidt, C. F., Elsom, K. A., and Johnston, C. G., Renal blood flow of unanesthetized rabbits and dogs in diuresis and antidiuresis. Am. J. Physiol., 1937, 118, 95.

20. Forster, R. P., An examination of some factors which alter glomerular activity in the rabbit kidney. Am. J. Physiol., 1947, 150, 523.

21. Newman, E. V., Therapeutic Conference. The treatment of heart failure. Part II. The use of diuretics. Bull. Johns Hopkins Hosp., 1947, 81, 430.

22. Blumgart, H. L., Gilligan, D. R., Levy, R. C., Brown, M. G., and Volk, M. C., Action of diuretic drugs. I. Action of diuretic drugs in normal persons. Arch. Int. Med., 1934, 54, 40.

23. Escher, D. J. W., Weston, R. E., Leiner, G., Leiter, L., and Goldat, S., The effect of aminophyllin on cardiac output and renal hemodynamics in man. Federation Proc., 1948, 7, 31.

24. James, D. F., Turner, H., and Merrill, A. J., Circulatory and renal effects of aminophylline in congestive heart failure. Am. J. Med., 1948, 5, 619.

25. Green, D. M., Bridges, W. C., Johnson, A. D., Lehmann, J. H., Gray, F., and Field, L., Xanthine studies: 2) effects of aminophylline, 1, 3 diethyl 8 bromoxanthine and 1, 3 dimethyl 8 chloroxanthine on water and sodium excretion. Federation Proc., 1949, 8, 296.

26. Chasis, H., Ranges, H. A., Goldring, W., and Smith, H. W., The control of renal blood flow and glomerular filtration in normal man. J. Clin. Invest., 1938, 17, 683.

27. Davis, J. O., and Shock, N. W., Theophylline ethylene diamine and renal function in control subjects and decompensated cardiac patients. Federation Proc., 1949, 8, 32.

28. Howarth, S., McMichael, J., and Sharpey-Schafer, E. P., The circulatory action of theophylline ethylene diamine. Clin. Sci., 1947, 6, 125.

29. Davies, D. F., and Shock, N. W., Age changes in glomerular filtration rate, effective renal plasma flow and tubular excretory capacity in adults. To be published.

30. Farnsworth, E. B., and Krakusin, J. S., Electrolyte partition in patients with edema of various origins. Qualitative and quantitative definition of cations and anions in cardiac decompensation. J. Lab. \& Clin. Med., 1948, 33, 1534.

31. Threefoot, S., Burch, G., and Reaser, P., The biologic decay periods of sodium in normal man, in patients with congestive heart failure, and in patients with the nephrotic syndrome as determined by $\mathrm{Na}^{20}$ as the tracer. J. Lab. \& Clin. Med., 1949, 34, 1. 